\title{
Sea Water Characterization at Ujung Kulon Coastal Depth as Raw Water Source for Desalination and Potential Energy
}

\author{
Dan Mugisidi ${ }^{1}$, and Okatrina Heriyani ${ }^{1 *}$ \\ ${ }^{1}$ Faculty of Engineering, Muhammadiyah Prof. Dr. HAMKA University, Jakarta - Indonesia
}

\begin{abstract}
Fresh water is basic need for life while the source is limited. Therefore, sea water is used as fresh water through desalination process. Sea water has different physical and chemical properties ranging from the surface to the seabed. The energy potential that can be obtained from the hydrostatic pressure also changes according to the depth. As part of the research of the utilization of sea water into fresh water, the aim of this study is to know the characteristics of sea water in the depth that can be utilized as source of fresh water. The sea water samples were taken at $11 \mathrm{~km}$ from Ujung Kulon beach with depth of 0m, 20m, $40 \mathrm{~m}, 60 \mathrm{~m}, 80 \mathrm{~m}$, and $100 \mathrm{~m}$ under the surface. The results showed that the physical properties at every depth were below the maximum allowable drinking water except for the amount of dissolved solids. Chemical characteristics at any depth above allowable level were fluoride, hardness (CaCo3), chloride, sodium, sulphate, and (KMnO4). In addition to the properties, pressure is one of the considerations in this study to determine the depth of sea water as sources for desalination. Pressure increased by $36.11 \%$ as the depth of the sea increased.
\end{abstract}

\section{Introduction}

Fresh water is a necessity for every creature on earth to stay alive. Population growth in Indonesia has a direct impact on the use of freshwater in the soil. This situation is completed with the reducing of water absorption area in various places due to the increase of buildings and factories. This resulted in the availability of clean water become threatened. UNICEF reports that 1 in 4 children will live in rare areas of water[1]. The condition is compounded by the decline in the soil surface due to the increasing amount of clean water taken from the soil[2]. Globally, water usage has tripled in the last 50 years[3], while the amount of fresh water on the surface of the earth is only $2.8 \%$ and the rest of $97.2 \%$ is sea water[4]. Therefore, the utilization of sea water as clean water becomes very potential. The problem is that seawater contains a greater amount of dissolved salt than fresh water, especially $\mathrm{NaCl}$. Table 1 shows the dissolved salt content in different oceans and oceans in different parts of the world. Therefore, efforts to convert sea water into fresh water and efforts to eliminate salt content from seawater are widely practiced.

Various desalination technologies and their combination with renewable energy are shown in Figure 1. The utilization of solar energy for the desalination process is the least costly way, especially in tropical regions such as Indonesia. Direct heating method with solar heat is the most suitable way to produce fresh water up to $200 \mathrm{~m}^{3} /$ day[5]. For larger scales, the use of solar energy coupled with other energy sources such as heat collectors, waves, and geothermal is sufficient[6].
Table 1. Mean Value of Total Dissolved Salts in Various Seas and Oceans ${ }^{[4]}$

\begin{tabular}{ll}
\hline \multicolumn{1}{c}{ Sea or Ocean TDS (ppm) } & \multicolumn{1}{c}{ Sea or Ocean TDS $(\mathrm{ppm})$} \\
\hline Baltic Sea 7000 & Indian Ocean 33,800 \\
Caspian Sea 13,500 & Mediterranean near Crete 37,900 \\
Black Sea 20,000 & Mediterranean 39,000 \\
White Sea 28,000 & Red Sea 43,000 \\
North Atlantic 29,000 & Arabian Gulf 50,000 \\
Pacific Ocean 33,600 & Australian Shark Bay 70,000 \\
Atlantic South 36,000 & Kara Bogas Gulf 164,000 \\
North Atlantic 36,200 & (in Caspian Sea) \\
Adriatic Sea 31,400 & Dead Sea 220,000 \\
\hline
\end{tabular}

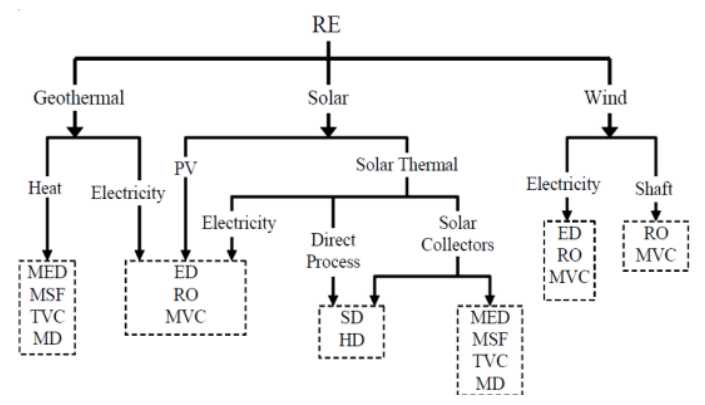

Fig. 1. Possible technological combinations of the main renewable energies and desalination methods[18] 
Renewable energies are energy sources that are continually replenished by nature and derived directly from the sun (such as thermal, photo-chemical, and photo-electric), indirectly from the sun (such as wind, hydropower, and photosynthetic energy stored in biomass), or from other natural movements and mechanisms of the environment (such as geothermal and tidal energy)[7]. The solar energy collector is one of the tools that developing in renewable energy. The various types of collectors such as flat-plate, compound parabolic, evacuated tube, parabolic trough, fresnel lens, parabolic dish, and Heliostat field collector (HFC) widely used as a tool for collecting solar energy[8]. Wind, solar, and other renewable technologies that can be used for desalination are rapidly emerging with the promise of economic and environmental viability on a large scale[9]. Renewable energy provides solutions to lower energy costs. One of the energy that can be utilized for the desalination process is hydrostatics pressure10. Hydrostatic pressure reduces the electricity consumption for the reverse osmosis process from 10 $\mathrm{kwh} / \mathrm{m}^{3}$ to $2.98 \mathrm{kwh} / \mathrm{m}^{3}[11]$. Efficiency of hydrostatic usage as energy source is $80 \%$ in desalination process with $\mathrm{RO}^{[12]}$.

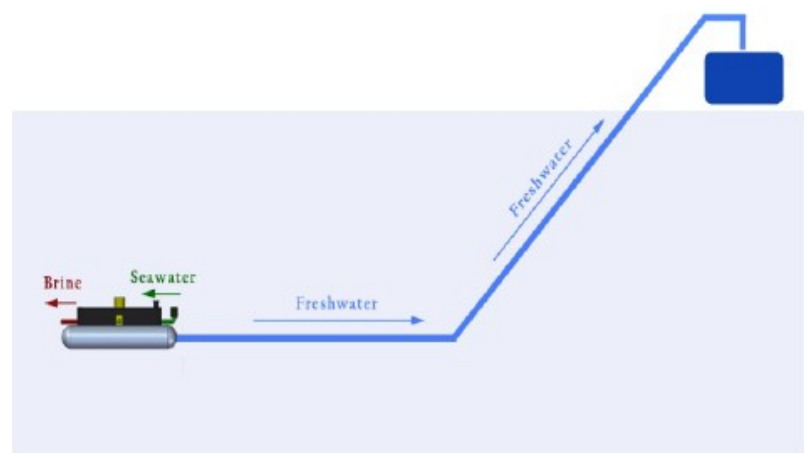

Fig. 2. Deep sea reverse Osmosis scheme[19]

At the depth of the ocean, the available pressure and power generated by the turbine can be estimated using the following equations ${ }^{[13]}$ :

$$
\begin{aligned}
& P=\rho \cdot g \cdot H \\
& P_{T}=Q \cdot \rho \cdot g \cdot H
\end{aligned}
$$

Where

$P$ is the pressure due to the height difference $\left(\frac{N}{\mathrm{~m}^{2}}\right)$,
$P_{\tau}$ is the power generated turbine (watt),

$\mathrm{Q}$ is Flow Rate $\left(\frac{\mathrm{m}^{3}}{\mathrm{~g}}\right)$,

$\rho$ is the density $\left(\frac{\mathrm{kg}}{\mathrm{m}^{3}}\right)$,

$g$ is gravity $9,81\left(\frac{m}{g^{2}}\right)$, and

$H$ is head difference $(m)$.

Utilization of hydro energy storage, where the water is taken from the depth of the ocean, the water will be different from the water on the surface, such as temperature. Since ocean's temperature decreases steadily with depth, although the ocean's surface temperature varies from $40^{\circ} \mathrm{C}$ to $-2^{\circ} \mathrm{C}$, the average temperature in ocean's depth is almost constant and around $3-4^{\circ} \mathrm{C}[14]$. In addition, sea water content will also change where salinity increased $4.52 \%, \mathrm{pH}$ decreased an average of $1.46 \%$ and the conductivity increase an average $0.03 \%$ in line with the addition of $\operatorname{depth}^{[15]}$.

In this study, the sample of sea water content was taken from depth $0 m, 20 m, 40 m, 60 m, 80 m$, and $100 m$. Tests were performed using drinking water standards. In addition, the potential power at each depth to be obtained will also be calculated

\section{Method}

The sea water used in this study was taken from offshore of Ujung Kulon, West Java, Indonesia. The depth of sampling is $0 \mathrm{~m}, 20 \mathrm{~m}, 40 \mathrm{~m}, 60 \mathrm{~m}, 80 \mathrm{~m}$, and $100 \mathrm{~m}$. Samples at each depth were taken as many as 40 liters and stored in jerrycan. Sampling is done by using 2 inch hose that closed at the end by using valve. The sample test was conducted at the Mechanical Engineering Laboratory, Prof. Dr. HAMKA University and at the Regional Health Laboratory (LABKESDA) of DKI Jakarta, in Rawasari. The comparative standard used is the drinking water standard applicable in the Republic of Indonesia, Permenkes 492 Tahun 2010[16].

\section{Result and Discussion}

In this study, the testing of sea water content taken from a depth of $0 \mathrm{~m}, 20 \mathrm{~m}, 40 \mathrm{~m}, 60 \mathrm{~m}, 80 \mathrm{~m}$, and $100 \mathrm{~m}$. The test is performed using the Drinking Water Standard as shown in Table 2.

\begin{tabular}{|c|c|c|c|c|c|c|c|c|}
\hline \multirow{2}{*}{ Parameter } & \multirow{2}{*}{ Satuan } & \multicolumn{6}{|c|}{ Kedalaman } & \multirow{2}{*}{$\begin{array}{c}\text { Kadar Maksimum yang } \\
\text { Diperbolehkan untuk Air } \\
\text { Minum }\end{array}$} \\
\hline & & $0 \mathrm{M}$ & $20 M$ & $40 M$ & $60 \mathrm{M}$ & $80 \mathrm{M}$ & $100 \mathrm{M}$ & \\
\hline Smell & - & \begin{tabular}{|l} 
Tidak \\
berbau
\end{tabular} & $\begin{array}{l}\text { Tidak } \\
\text { berbau }\end{array}$ & $\begin{array}{l}\text { Tidak } \\
\text { berbau }\end{array}$ & \begin{tabular}{|l} 
Tidak \\
berbau
\end{tabular} & \begin{tabular}{|l} 
Tidak \\
berbau
\end{tabular} & $\begin{array}{l}\text { Tidak } \\
\text { berbau }\end{array}$ & Tidak berbau \\
\hline TDS & $\mathrm{mg} / \mathrm{l}$ & 29,535 & 30,125 & 29,425 & 29,928 & 30,076 & 30,927 & 500 \\
\hline Turbidity & & 0.36 & 0.27 & 1.84 & 0.33 & 77.1 & 0.34 & 5 \\
\hline Temperature & Skala NTU & 25.6 & 25.3 & 25.8 & 25.5 & 25.9 & 25.8 & Suhu udara $\pm 3^{0}$ \\
\hline Color & Skala TCU & $\mathrm{tt}<2$ & $\mathrm{tt}<2$ & $\mathrm{tt}<2$ & $\mathrm{tt}<2$ & $\mathrm{tt}<2$ & $\mathrm{tt}<2$ & 15 \\
\hline
\end{tabular}

Table 2. Physical Properties according to $492 / 2010$

Table 2 is the result of testing of seawater physical properties that follow to the standard on drinking water testing. The test results showed that TDS (Total
Dissolved Solid) was in the range of $30,000 \mathrm{mg} / \mathrm{l}$, while the standard allowed for drinking water was $500 \mathrm{mg} / \mathrm{l}$. In addition, turbidity at a depth of $80 \mathrm{~m}$ differs from other 
depths. At a depth of $0 m, 20 m, 40 m, 60 m$, and $100 m$ average turbidity is 0.628 below the drinking water standard, 5. Turbidity at a depth of $80 \mathrm{~m}$ is different because at that depth there is undersea water flow. This is evidenced by the carrying of a hose by the water current at the depth. Furthermore, the chemical properties of seawater are shown in Table 3.
In Table 3, it appears that parameters that exceed the maximum permissible levels of drinking water are Flouride, Hardness, Chloride, Sodium, Sulfate, and Organic. This is consistent with that stated by Vassilis Belesiotis, et. $\mathrm{Al}[4]$.

Table 3. Chemical Properties according to 492/2010

\begin{tabular}{|c|c|c|c|c|c|c|c|c|}
\hline \multirow{2}{*}{ Parameter } & \multirow{2}{*}{ Satuan } & \multicolumn{6}{|c|}{ Kedalaman } & \multirow{2}{*}{$\begin{array}{c}\text { Kadar Maksimum yang } \\
\text { Diperbolehkan untuk } \\
\text { Air Minum }\end{array}$} \\
\hline & & $\mathbf{0} \mathbf{M}$ & $20 \mathrm{M}$ & $40 \mathrm{M}$ & $60 \mathrm{M}$ & $80 \mathrm{M}$ & $100 \mathrm{M}$ & \\
\hline Mercury & $\mathrm{mg} / \mathrm{l}$ & $\mathbf{t t}<\mathbf{0 . 0 0 0 5}$ & $\mathbf{t t}<\mathbf{0 . 0 0 0 5}$ & $\mathbf{t t}<\mathbf{0 . 0 0 0 5}$ & $\mathbf{t t}<\mathbf{0 . 0 0 0 5}$ & $\mathbf{t t}<\mathbf{0 . 0 0 0 5}$ & $\mathbf{t t}<\mathbf{0 . 0 0 0 5}$ & $\begin{array}{r}0.001 \\
\end{array}$ \\
\hline Alumunium & $\mathrm{mg} / \mathrm{l}$ & $\mathbf{t t}<\mathbf{0 . 0 1 2 7}$ & $\mathbf{t t}<\mathbf{0 . 0 1 2 7}$ & $\mathbf{0 . 0 5 8 6}$ & $\mathbf{t t}<\mathbf{0 . 0 1 2 7}$ & $\mathbf{0 . 0 8 5 1}$ & $\mathbf{t t}<\mathbf{0 . 0 1 2 7}$ & 0.2 \\
\hline Arsen & $\mathrm{mg} / \mathrm{l}$ & $\mathbf{t t}<\mathbf{0 . 0 0 2 1}$ & $\mathrm{tt}<\mathbf{0 . 0 0 2 1}$ & $\mathbf{t t}<\mathbf{0 . 0 0 2 1}$ & $\mathbf{t t}<0.0021$ & $\mathrm{tt}<\mathbf{0 . 0 0 2 1}$ & $\mathbf{t t}<\mathbf{0 . 0 0 2 1}$ & 0.01 \\
\hline Barium & $\mathrm{mg} / \mathrm{l}$ & $\mathbf{t t}<\mathbf{0 . 0 0 2 3}$ & $\mathbf{t t}<\mathbf{0 . 0 0 2 3}$ & $\mathbf{t t}<\mathbf{0 . 0 0 2 3}$ & $\mathbf{t t}<\mathbf{0 . 0 0 2 3}$ & $\mathbf{t t}<\mathbf{0 . 0 0 2 3}$ & $\mathbf{t t}<\mathbf{0 . 0 0 2 3}$ & 0.7 \\
\hline Ferrous & $\mathrm{mg} / \mathrm{l}$ & $\mathrm{tt}<\mathbf{0 . 0 1 7 8}$ & $\mathbf{t t}<\mathbf{0 . 0 1 7 8}$ & $\mathbf{t t}<\mathbf{0 . 0 1 7 8}$ & $\mathrm{tt}<0.0178$ & $\mathrm{tt}<\mathbf{0 . 0 1 7 8}$ & $\mathbf{t t}<\mathbf{0 . 0 1 7 8}$ & 0.3 \\
\hline Fluoride & $\mathrm{mg} / \mathrm{l}$ & 1.65 & 2.14 & 1.62 & \begin{tabular}{r|}
1.8 \\
\end{tabular} & 1.73 & $\begin{array}{r}1.9 \\
\end{array}$ & 1.5 \\
\hline Cadmium & $\mathrm{mg} / \mathrm{l}$ & $\mathbf{t t}<\mathbf{0 . 0 0 0 3}$ & $\mathrm{tt}<\mathbf{0 . 0 0 0 3}$ & $\mathbf{t t}<\mathbf{0 . 0 0 0 3}$ & $\mathbf{t t}<0.0003$ & $\mathbf{t t}<0.003$ & $\mathbf{t t}<\mathbf{0 . 0 0 0 3}$ & 0.003 \\
\hline Hardness $\left(\mathrm{CaCO}^{3}\right)$ & $\mathrm{mg} / \mathrm{l}$ & 6313 & 6653 & 6473 & 6693 & 6633 & 7515 & 500 \\
\hline Chloride & $\mathrm{mg} / \mathrm{l}$ & 20621 & 20783 & 20358 & 20648 & 20855 & 20771 & 250 \\
\hline \begin{tabular}{|l|} 
Chromium Total \\
\end{tabular} & $\mathrm{mg} / \mathrm{l}$ & $\mathbf{t t}<\mathbf{0 . 0 0 0 4}$ & $\mathbf{t t}<\mathbf{0 . 0 0 0 4}$ & $\mathbf{t t}<\mathbf{0 . 0 0 0 4}$ & $\mathbf{t t}<\mathbf{0 . 0 0 0 4}$ & $\mathbf{t t}<\mathbf{0 . 0 0 0 4}$ & $\mathbf{t t}<\mathbf{0 . 0 0 0 4}$ & 0.05 \\
\hline Manganese & $\mathrm{mg} / \mathrm{l}$ & $\mathbf{t t}<\mathbf{0 . 0 0 0 7}$ & $\mathbf{t t}<\mathbf{0 . 0 0 0 7}$ & $\mathbf{t t}<\mathbf{0 . 0 0 0 7}$ & $\mathbf{t t}<\mathbf{0 . 0 0 0 7}$ & $\mathbf{t t}<\mathbf{0 . 0 0 0 7}$ & $\mathbf{t t}<\mathbf{0 . 0 0 0 7}$ & 0.4 \\
\hline Sodium & $\mathrm{mg} / \mathrm{l}$ & \begin{tabular}{|r|}
5380 \\
\end{tabular} & 5141 & 4718 & \begin{tabular}{|l|}
4662 \\
\end{tabular} & 4526 & \begin{tabular}{|r|}
4449 \\
\end{tabular} & 200 \\
\hline Nitrate & $\mathrm{mg} / \mathrm{l}$ & $\mathrm{tt}<\mathbf{0 . 2 1 1}$ & $\mathrm{tt}<0.211$ & $t \mathrm{tt}<0.211$ & $\mathrm{tt}<0.211$ & $\mathrm{tt}<\mathbf{0 . 2 1 1}$ & $\mathrm{tt}<\mathbf{0 . 2 1 1}$ & 50 \\
\hline Nitrite & $\mathrm{mg} / \mathrm{l}$ & $\mathbf{t t}<\mathbf{0 . 0 1 2}$ & $\mathbf{t t}<\mathbf{0 . 0 1 2}$ & $\mathbf{t t}<\mathbf{0 . 0 1 2}$ & $\mathbf{t t}<\mathbf{0 . 0 1 2}$ & $\mathbf{t t}<\mathbf{0 . 0 1 2}$ & $\mathbf{t t}<\mathbf{0 . 0 1 2}$ & 3 \\
\hline pH & - & \begin{tabular}{|l|}
7.67 \\
\end{tabular} & 7.63 & \begin{tabular}{|r|}
7.3 \\
\end{tabular} & \begin{tabular}{|l|}
7.61 \\
\end{tabular} & \begin{tabular}{|l|}
7.17 \\
\end{tabular} & \begin{tabular}{|r|}
6.87 \\
\end{tabular} & $6.5-8.5$ \\
\hline Selenium & $\mathrm{mg} / \mathrm{l}$ & $\mathbf{t t}<\mathbf{0 . 0 0 2 1}$ & $\mathbf{t t}<\mathbf{0 . 0 0 2 1}$ & $\mathbf{t t}<\mathbf{0 . 0 0 2 1}$ & $\mathbf{t t}<0.0021$ & $\mathbf{t t}<\mathbf{0 . 0 0 2 1}$ & $\mathbf{t t}<\mathbf{0 . 0 0 2 1}$ & 0.01 \\
\hline Zine & mg// & $\mathbf{t t}<\mathbf{0 . 0 3 3 5}$ & $\mathbf{t t}<\mathbf{0 . 0 3 3 5}$ & $\mathbf{t t}<\mathbf{0 . 0 3 3 5}$ & $\mathbf{t t}<\mathbf{0 . 0 3 3 5}$ & $\mathbf{t t}<\mathbf{0 . 0 3 3 5}$ & $\mathbf{t t}<\mathbf{0 . 0 3 3 5}$ & 3 \\
\hline Cyanide & $\mathrm{mg} / \mathrm{l}$ & $\mathbf{t t}<\mathbf{0 . 0 0 1 5}$ & $\mathrm{tt}<\mathbf{0 . 0 0 1 5}$ & $\mathbf{t t}<\mathbf{0 . 0 0 1 5}$ & $\mathbf{t t}<\mathbf{0 . 0 0 1 5}$ & $\mathbf{t t}<\mathbf{0 . 0 0 1 5}$ & $\mathbf{t t}<\mathbf{0 . 0 0 1 5}$ & 0.07 \\
\hline Sulfate & $\mathrm{mg} / \mathrm{l}$ & 2584 & 2580 & 2549 & 2546 & 2561 & 2548 & 250 \\
\hline Copper & mg// & $\mathbf{t t}<\mathbf{0 . 0 0 0 4}$ & $\mathbf{t t}<\mathbf{0 . 0 0 0 4}$ & $\mathbf{t t}<\mathbf{0 . 0 0 0 4}$ & $\mathbf{t t}<\mathbf{0 . 0 0 0 4}$ & $\mathbf{t t}<\mathbf{0 . 0 0 0 4}$ & $\mathbf{t t}<\mathbf{0 . 0 0 0 4}$ & 2 \\
\hline Lead & mg/l & $\mathbf{t t}<\mathbf{0 . 0 0 1 3}$ & $\mathrm{tt}<\mathbf{0 . 0 0 1 3}$ & $\mathbf{t t}<\mathbf{0 . 0 0 1 3}$ & $\mathbf{t t}<0.0013$ & $\mathrm{tt}<\mathbf{0 . 0 0 1 3}$ & $\mathbf{t t}<\mathbf{0 . 0 0 1 3}$ & 0.01 \\
\hline Ammonia & $\mathrm{mg} / \mathrm{l}$ & $\mathbf{t t}<\mathbf{0 . 0 2}$ & $\mathbf{t t}<\mathbf{0 . 0 2}$ & $\mathbf{t t}<\mathbf{0 . 0 2}$ & $\mathbf{t t}<\mathbf{0 . 0 2}$ & $\mathbf{t t}<\mathbf{0 . 0 2}$ & $\mathbf{t t}<\mathbf{0 . 0 2}$ & 1.5 \\
\hline Organic $\left(\mathrm{KmnO}_{4}\right)$ & mg/l & 111.76 & 119.46 & 145.67 & \begin{tabular}{|r|}
116.38 \\
\end{tabular} & 141.04 & 148.75 & 10 \\
\hline Nickel & $\mathrm{mg} / \mathrm{l}$ & $\mathbf{t t}<\mathbf{0 . 0 0 0 3}$ & $\mathbf{t t}<\mathbf{0 . 0 0 0 3}$ & $\mathbf{t t}<\mathbf{0 . 0 0 0 3}$ & $\mathbf{t t}<0.0003$ & $\mathrm{tt}<\mathbf{0 . 0 0 0 3}$ & $\mathbf{t t}<\mathbf{0 . 0 0 0 3}$ & 0.07 \\
\hline
\end{tabular}

Furthermore, data that is above the maximum level shown in Figure 3. In Figure 3, TDS that is above the maximum level increases with increasing depth. An average TDS increase of $10 \%$ for every $20 \mathrm{~m}$ depth increase. Turbidity at depths of $0 \mathrm{~m}, 20 \mathrm{~m}, 40 \mathrm{~m}, 60 \mathrm{~m}$, and $100 \mathrm{~m}$ below permissible levels except at a depth of $80 \mathrm{~m}$.

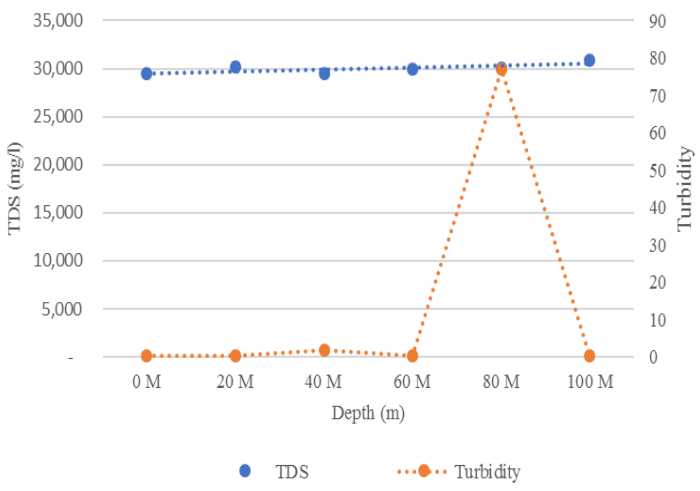

Fig. 3. Physical Properties TDS and Turbidity

In Figure 4, it appears that organic increases by $30 \%$ in line with increasing ocean depth. Mean while, on the average of flouride is no increase with the depth of the sea. This is in line with that proposed by Bewers ${ }^{[17]}$ that there is no increase in levels of fluoride along with the addition of the depth of the ocean.

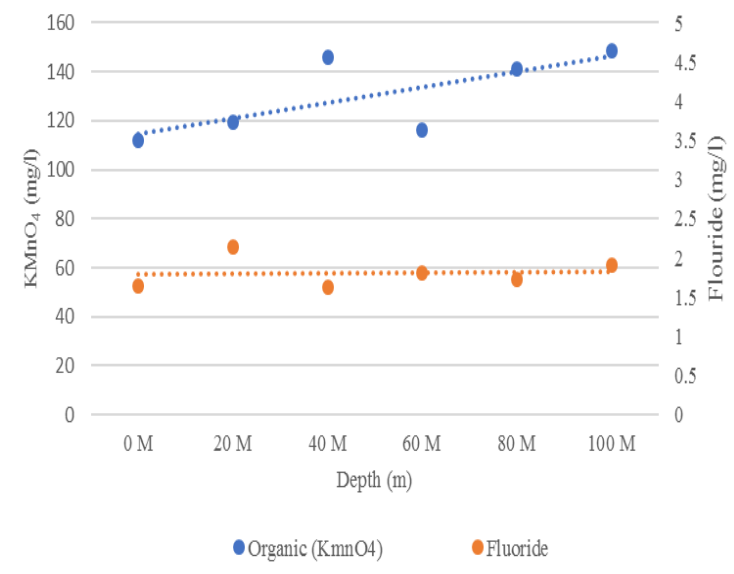

Fig. 4. Chemical Properties Organic and Flouride

The increase also does not occur in Chloride and Sulphate, as can be seen in Figure 5. In contrast to other elements, sodium has decreased by $20 \%$ with increasing sea depth, while Hardness is up $23 \%$ along with increasing depth of sea depth. 


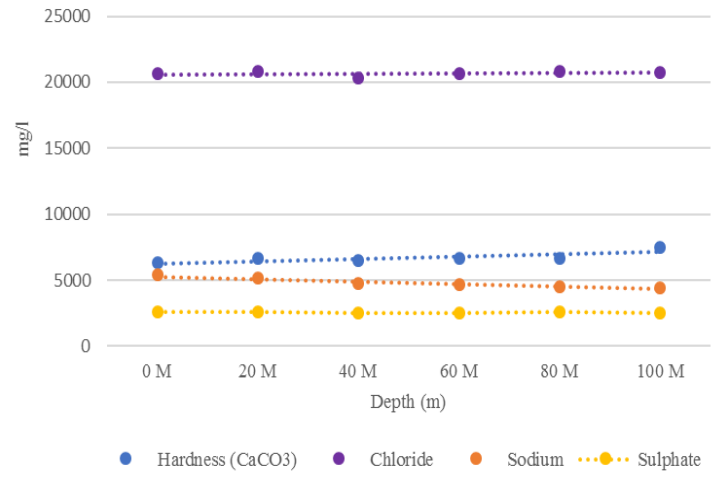

Figure 5. Chemical Properties ; Hardness, Chloride, Sodium and Sulphate

In addition to sea water testing, the potential power obtained by the pressure due to the depth of the sea is calculated, assuming the water requirement is $\quad 200$ liters/person/day with the population on one island is 100 people, then the required debit is 20,000 liters/day or $0.8 \mathrm{~m}^{3} /$ hour. The gravity of sea water is $1.025 \mathrm{~kg} / \mathrm{m}^{3}$ and gravity is $9.81 \mathrm{~m} / \mathrm{s}^{2}$, the increase in hydrostatic pressure is $36.11 \%$ with increasing sea depth.

\section{Conclusions}

Based on the results of the test, it can be concluded that TDS, hardness, sodium, and organic have changed sequentially by $10 \%, 23 \%,-20 \%$, and $30 \%$. Flouride, chloride, and sulphate do not change with increasing sea depth. Potential pressure increased by $36.11 \%$ with increasing sea depth.

\section{References}

1. "UNICEF: 1 dari 4 Anak akan Tinggal di Daerah Langka Air" | Republika Online. http://www.republika.co.id/berita/internasional/glo bal/17/03/23/on8xa8384-unicef-1-dari-4-anakakan-tinggal-di-daerah-langka-air. Accessed June 29, (2017).

2. "Krisis Air Bersih di Jakarta Berdampak pada Penurunan Muka Tanah" | Republika Online. http://nasional.republika.co.id/berita/nasional/jabod etabek-nasional/16/10/26/ofnh6z335-krisis-airbersih-di-jakarta-berdampak-pada-penurunanmuka-tanah. Accessed June 29, (2017).

3. Vigotti R, Hoffman A. The water scarcity and
Water Scurity: po;itical and Social implications. In: Technology and Water, Rome: IEA Working Party, (2009).

4. V. Belessiotis, S. Kalogirou, E. Delyannis, 1St ed. (Convey M, ed.), ELSEVIER, (2016).

5. Garcia-Rodriguez L. Seawater desalination driven by renewable energies: a review, Desalination, (2002).

6. M. Shatat, S. Riffat, S. Ghabayen, SIn: The 4th International Engineering Conference -Towards Engineering of 21st Century, 1-16, (2012).

7. O. Ellabban, F. Blaabjerg, Renew Sustain Energy Rev, 39(August), 748-764, (2014). doi:10.1016/j.rser.2014.07.113.

8. SA. Kalogirou, Solar Thermal Collectors and Applications, Vol 30, (2004). doi:10.1016/j.pecs.2004.02.001.

9. S. Kalogirou, Prog energy Combust Sci. (2005). doi:10.1016/j.pecs.2005.03.001.

10. C. Charcosset, Desalination, (2009).

11. C.Charcosset. Renew Energy, 34 (12), 2878-2882, (2009). doi:https://doi.org/10.1016/j.renene.2009.02.026.

12. M. Reali, M. de Gerloni, A. Sampaolo, Desalination, 109(3), 269-275, (1997). doi:10.1016/S0011-9164(97)00073-8.

13. F. Dietzel, Turbin, Pompa Dan Kompresor, Ketiga, Erlangga, (1992).

14. PR. Pinet Invitation to Oceanography, Jones and Bartlett Publishers, (2009).

15. D. Mugisidi, O. Heriyani, Prosiding Seminar Internasional Universitas Muhammadiyah Purwokerto, (2016).

16. Permenkes RI. PMK No. 492 ttg Persyaratan Kualitas Air Minum.pdf, (2010).

17. JM. Bewers, Deep Sea Res Oceanogr Abstr,18 (2), 237-241, (1971). doi:10.1016/00117471(71)90113-6.

18. AE. Kabeel, SA. El-Agouz, R Desalination, 276 (1-3),1-12, doi:10.1016/j.desal.2011.03.042.

(2011).

19. R. Dashtpour, SN. Al-Zubaidy, International Proceedings of Chemical, Biological and Environmental Engineering. Vol 33, 154-162, (2012). http://ipcbee.com/vol33/031-ICEEB2012B20001.pdf. 